\title{
Jak v etnografickém výzkumu získat př́stup: zkušenosti s romskou populací
}

\author{
Michal Vavroch \\ Katedra antropologie Fakulty filozofické Západočeské univerzity v Plzni, Sedláčkova 15, 30614 Plzeň \\ Do redakce doručeno 17. března 2013; k publikaci přijato 6. června 2013
}

\section{HOW TO GAIN AN ACCESS IN ETHNOGRAPHIC RESEARCH: EXPERIENCES WITH ROMA POPULATION}

\begin{abstract}
The article addresses the painful initial phase of participant observation, which is to gain access to the population studied. Relevant literature, which served to the author as a guide in designing his own strategies is presented. Author describes in detail his own experiences with conducting research in a the difficult environment of Roma locality. He reveals his fallacious decisions, adversities and lack of usable skills enabling active participation. In addition to his successful strategy he presents alternative proposals to gain access. The purpose of the paper is not another „demystification“ of fieldwork through exhibitionistic self-reflection but to give a realistic picture for novice researchers who intend to pursue own research in a similar environment.
\end{abstract}

KEY WORDS Field Research; Gaining Access; Roma/Gypsy; Barriers to Interaction

ABSTRAKT Článek se věnuje složité úvodní fázi zúčastněného pozorování, kterou je získání prístupu mezi studovanou populaci. Představuje relevantní odbornou literaturu, která sloužila autorovi jako vodítko při navrhování vlastních strategií navázání kontaktů s informanty. Detailně popisuje autorovy zkušenosti s vlastním výzkumem v obtížném prostředí romské lokality. Odhaluje mylná rozhodnutí, projevy nepřízně osudu i absenci prakticky využitelných dovedností umožňujících aktivní participaci. Kromě vlastní úspěšné strategie předkládá alternativní návrhy, jak získat př́stup. Účelem př́spěvku není přispět $\mathrm{k}$ další „demystifikaci” práce v terénu prostřednictvím exhibicionistické sebereflexe, ale poskytnout realistický obraz začínajícím badatelům, kteří se budou chtít vydat do podobného prostředí.

KLÍČOVÁ SLOVA terénní výzkum; získávání př́stupu; romové/cikáni; bariéry v interakci

Tento př́spěvek vznikl také díky finanční podpoře Vnitřního grantového řízení Fakulty filosofické Západočeské univerzity v Plzni pro rok 2013. Děkuji Michalu Rủžičkovi a Gabriele Fatkové za všechny užitečné připomínky, postřehy, rady a návrhy na úpravy, které mi k pracovním verzím textu poskytli, a Marku Jakoubkovi za podporu při mých snahách proniknout mezi studovanou populaci.

\section{ÚVOD}

Etnografie je vědou i uměním a etnograf vědcem i vypravěčem. Jeho práce se blíží investigativní žurnalistice: vyzpovídává klíčové osoby, analyzuje jejich výpovědi a vzájemně je porovnává. Rozdíl tkví v tom, že zatímco novinár hledá neobvyklé senzace, etnograf popisuje běžnou každodennost života lidí (Fetterman 98, s. 473-74). Obvykle se doporučuje alespoň roční terénní výzkum v přirozeném prostředí zkoumané populace (Dewalt et al. 1998, s. 270). Až na výjimečné př́pady se etnograf nestává skutečným členem skupiny, což mu nijak nebrání se zapojovat do jejích každodenních aktivit tak, jako by jím skutečně byl (Wax M.; Wax R. 1980, s. 30). Uvedená metoda terénního výzkumu se nazývá zúčastněné pozorování. ${ }^{1}$ Nejsložitější součást zúčastněného pozorování představuje

1 Jinými slovy se nejedná o synonymní označení jedné metody. Např́klad výzkum pohlavních chorob u prostitutek je náročným terénním výzkumem, ale rozhodně se nejedná o zúčastněné pozorování (Bernard 2006, s. 343). 
ve většině př́ípadů získání přístupu mezi studovanou populaci (Bernard 2006, s. 356). Metaforicky lze tento proces připodobnit k hledání správných dveří v prostorné hale. Některé jsou zavřené, jiné otevřené a další jen tak napůl. Jedny vedou do míst, kde se může spoustu dozvědět, za jinými čekají prázdné místnosti. Na výzkumníkovi leží úkol vzbudit u lidí na druhé straně dveř́ takovou pozornost, aby jej pozvali mezi sebe a nechali nahlédnout do svých životů (Feldman et al. 2003, ix-x). Jinak řečeno, získávání prŕístupu není jednostranným procesem, kde by si výzkumník své informanty vybíral, spíše je tomu naopak.

Ideální vztah výzkumníka s informanty se v anglofonní literatuře označuje jako rapport. Jedná se spíše o ideální koncept než dosažitelný stav, kdy je výzkumník přijat mezi členy studované populace a $\mathrm{z}$ jeho informantů se stávají jeho spolupracovníci (srov. Marcus 1997). Ačkoli je zřejmé, že př́stup a rapport se vzájemně prolínají, je třeba je analyticky odlišit. Vrátíme-li se $\mathrm{k}$ metafoře s dveřmi, pak prístup znamená pozvání na návštěvu, rapport prrátelský vztah s hostiteli budovaný prostřednictvím vzájemné interakce.

Předkládaný příspěvek se zaměřuje na získávání přístupu mezi romskou populaci, jejíž vnitřní identifikace je $\mathrm{z}$ nezanedbatelné části postavena na opozici vůči dominantní společnosti (srov. Pelikán 2011). Kromě vlastních zkušeností s výzkumem se opírá o poznatky z metodologické literatury a etnografických textů, které sloužily jako inspirace při navrhování vlastních strategií. K sepsání příspěvku vedly dva důvody. Romové představují z hlediska sociokulturního výzkumu v českém prostředí tradiční předmět zájmu, ale navzdory této skutečnosti není otázka získávání přístupu mezi romskou populaci náležitě zpracována. ${ }^{2}$ Učelem bylo využít těžce nabytých zkušeností $\mathrm{k}$ vytvoření vodítka zejména začínajícím badatelům při jejich vlastním výzkumu.

Lze konstatovat, že v české odborné literatuře není otázce získávání prrístupu věnována patřičná pozornost ani $\mathrm{v}$ jiných výzkumných kontextech. Předkládaný příspěvek se nesnaží tento nedostatek odstranit. Jeho cílem je poskytnout širšímu čtenářstvu detailní vhled do běžných problémů terénního výzkumu, nebot' je zřejmé, že „z mnohem otevřenějšího sdílení našich zkušeností bychom mohli profitovat my všichni, kdo se kvalitativním výzkumem zabýváme“ (Lareau 1996, s. 198).

\section{VÝZKUM BARIÉR}

Předmět mého zájmu představují bariéry $\mathrm{v}$ interakci mezi Čechy a Romy. Výzkum je realizován v sociálně vyloučené lokalitě $\check{\varkappa}^{3}$ nacházející se v obci s přibližně 10 tisíci obyvateli,

2 Rozsáhlejším textem na toto téma je stat Budilové a Jakoubka (2006) věnovaná specifikám genealogické metody v romských osadách na Slovensku.

3 Pro patřičné vysvětlení konceptu sociálního vyloučení zde není prostor. Velice zjednodušeně jde o situaci, kdy jsou jedinci či skupiny vyloučeni z běžných sociálních vztahů a je jim znesnadňován prŕstup k institucím, které mají ostatní občané státu k dispozici. Nejčastěji kterou během 90 . let 20. století bolestivě zasáhla všeobecná deindustrializace. Prostřednictvím výzkumu, který je zjednodušeně a možná výstižněji informantům předkládán jako problém "proč spolu Češi a Cigáni nemluví", usiluji identifikovat faktory, které ovlivňují zjevnou absenci harmonického soužití Romů s majoritou. ${ }^{4}$ Původní plán výzkumu počítal s pětiměsíčním sběrem dat v dané čtvrti (červen - říjen 2012). $\mathrm{Na}$ něj měl následujícího roku navazovat obdobný výzkum v jiném regionu, který by umožnil vzájemnou komparaci. Přes krátkodobé úspěchy se získání přístupu mezi obyvatele sledované čtvrti nepodařilo, a proto byl pobyt prodloužen o další rok.

\section{VÝBĚR LOKALITY}

Již při sestavování výzkumného designu je třeba mít otázku přístupu na zřeteli. Někdy se dokonce postupuje tak, že výzkum navrhujeme podle toho, jaké jsou v tomto ohledu naše možnosti (Feldman et al. 2003, s. 4). Pro volbu dané lokality hovořila právě možnost potenciálně snadnějšího přístupu mezi zkoumanou populaci. S romskou čtvrtí jsem se seznámil před lety při jednom drobnějším výzkumu pro místní neziskovou organizaci. Nyní jsem hodlal využít svých dobrých vztahů s jejími zaměstnanci a také se obrátit na respondenty, kteří se předchozího výzkumu účastnili. Stejně důležité kritérium výběru představoval profil čtvrti $\mathrm{z}$ hlediska etnického složení.

Lokalita je charakteristická dlouhodobou prostorovou koexistencí Čechů a Romů, nebot' první romské rodiny se zde usídlily již $\mathrm{v}$ poválečném období. Během minulého režimu žili čeští a romští starousedlíci vedle sebe jako běžní sousedé, kteří se potkávali v zaměstnání, na ulici a vzájemně se navštěvovali. Ochladnutí vztahů způsobila privatizace nekvalitního bytového fondu obce v 90 . letech 20 . století, která v důsledku vedla k navýšení počtu (marginalizovaných) Romů. Svůj podíl nesl také úbytek pracovních míst pro nekvalifikované romské dělníky, kteří následně začali být v očích majority vnímáni jako neužiteční (srov. Ladányi; Szelényi 2006).

Tato unikátní konstelace byla ideální z hlediska výchozího - značně nadneseného a později redukovaného - návrhu výzkumu, který počítal se sledováním kulturních, ekonomických a prostorových vlivů na charakter vzájemné komunika-

postihuje menšiny, nedostatečně vzdělané, hendikepované, ale i seniory či svobodné matky. V ČR se za sociálně vyloučenou lokalitu obvykle považuje prostor s nízkou kvalitou bydlení, kde žije relativně silná romská menšina. Srov. např. Mareš 2000, Mareš a Sirovátka 2008, Moravec 2009.

$4 \mathrm{~V}$ česko-slovenském prostředí se mezi referovanou populací označení Rom příliš neujalo. Podle některých autorů je hlavním důvodem skutečnost, že Cikáni a Romové - podobně jako Manušové, Sinti a další - představují dvě odlišné podskupiny populace, kterou bychom měli celkově nazývat jako Cikáni. Viz například Fraser 2002 či Cohn 2009. V textu je dána přednost termínu Rom, nebot’ na něj není vázáno tolik negativních konotací jako u preferovaného auto-etnonyma místních Romů, jímž je označení „Cigán“ (tj. psáno s g). 
ce. Za užitečnou lze považovat i silnou „cikánofobii” na straně úřadů, škol i řadových obyvatel města, na níž by bylo možné sledovat bariéry kladené majoritou.

\section{TEORETICKÁ VÝCHODISKA}

Teoretické ukotvení výzkumu lze $\mathrm{v}$ tomto příspěvku pouze načrtnout, nebot’ akademická debata týkající se Romů je značně rozsáhlá a složitá. Vedle toho se teoretický rámec výzkumu stále ještě konsoliduje s ohledem na přibývající data. $\mathrm{V}$ prrípadě studia Romů existují dvě do určité míry protikladná a zároveň komplementární hlediska. $\mathrm{V}$ prvé řadě se lze zaměřit na životní strategie Romů z pohledu jejich společenské marginalizace. Tento směr bádání je do značné míry slepý ke kultuře postižených skupin a klade důraz na vnější podmínky, které zapříčiňují, že se životní strategie marginalizovaných $\mathrm{v}$ řadě aspektů podobají (Lewis 1998, s. 7). Z tohoto důvodu se tato práce inspiruje řadou (urbánních) etnografií, které nemají s Romy zhola nic společného. Druhý směr bádání uchopuje Romy prostřednictvím konceptu kultury jako svébytné a jedinečné společenství. Třebaže vnitřně natolik diferencované, že se jednotlivé romské skupiny $\mathrm{v}$ některých případech mohou lišit více mezi sebou než vůči majoritní populaci (srov. Jakoubek 2004, s. 261). Cikánologové se obvykle zabývají sociální organizací, příbuzenstvím, jazykem a dalšími aspekty romských/cikánských kultur. Nelze opomenout ani romistické práce, které se věnují především romskému folkloru.

Jako vhodný nástroj se v kontextu bariér v interakci jeví koncept etnicity, který zohledňuje kulturní specifičnost, aniž by kladl rovnítko mezi „etnickou skupinu“ a „kulturu“. Ve skutečnosti se kulturní fenomény často vyskytují napříč hranicemi etnických skupin (Eriksen 2012, s. 68). Z tohoto pohledu nejsou bariéry v interakci mezi Čechy a Romy založeny na vzájemně neslučitelné kulturní odlišnosti. Vyzdvihovány jsou pouze některé kulturní prvky, zatímco řada jiných (sdílených) je přehlížena či popírána (Barth 1969, s. 14). Podle T. Eriksena se dokonce etnicita „nejdůležitější stává tam, kde si jsou skupiny kulturně blízké a pravidelně vstupují do vzájemného kontaktu“ (2001, s. 262). Koncept se jeví jako vhodný i z toho důvodu, že etnicitu chápe jako výsledek oboustranného vyjednávání, nikoli neměnnou vlastnost skupiny. V neposlední řadě upozorňuje na významnou korelaci mezi etnicitou a společenskou hierarchií, tedy „pravděpodobnost, že osoby př́slušející ke specifické etnické skupině zároveň patří k určité sociální třídě“ (Eriksen 2012, s. 30).

\section{METODOLOGIE}

Při navrhování výzkumného designu byla zvolena metoda polostrukturovaného rozhovoru. Výzkumník při ní neklade př́mé otázky, ale předkládá dotazovaným témata, která jej zajímají. Předem připravený soupis témat („návod“) zajištuje kontrolu nad průběhem rozhovoru a zároveň ponechává možnost sledovat nové směry dotazování. (Bernard 2000, s. 191). Mnou sestavený „návod“ se snažil zohlednit kulturní odlišnosti i rozdílné socioekonomické postavení, které by mohly zakládat vzájemné nedorozumění. ${ }^{5}$ Při testování tohoto nástroje se ukázalo, že jak témata, tak samotná strukturace (otázka - odpověd') neodpovídaly naturelu dotazovaných. ${ }^{6}$

Předkládané náměty se jevily jako nepodnětné, nebot' se o nich respondenti nedokázali sami rozhovořit. Měli tendenci se zabývat pouze líčením situací, kdy na nich byla ze strany majority páchána nějaká křivda. Odpovědi rovněž vyvolávaly podezření, že jsou stylizované podle jejich představy o tom, co si výzkumník přeje slyšet. Ukázalo se, že př́mé dotazování bez důvěry (rapportu) $\mathrm{k}$ tazateli nevede $\mathrm{k}$ zisku relevantních dat. Nedůvěra pramenící $\mathrm{z}$ příslušnosti $\mathrm{k}$ majoritní společnosti se projevovala i v jiných kontextech. Např́klad během prvního týdne jsem pozoroval muže, jak u veřejné fontánky plní kanystry vodou. Ve snaze zapříst rozhovor jsem k němu přistoupil a zúčastněně se ho otázal „vám neteče voda?" $\mathrm{V}$ domnění, že bych mohl být někým ze sociálního odboru, mi dotyčný př̀es zjevnost celé situace odvětil „ne, ne, to mám na kafe".

O identických zkušenostech píše R. Waxová, která prováděla během II. světové války výzkum $\mathrm{v}$ americkém internačním táboře pro Japonce. Přestože se odehrával v jednoznačně nepř́íznivém kontextu, předpokládala, že upřímný zájem o problémy internovaných povede $\mathrm{k}$ překonání jejich odtažitosti. Její očekávání se nepotvrdila. Internovaní ji bud’ ignorovali nebo se taktéž omezovali na odpovědi, které podle jejich názoru chtěla slyšet. Po měsíci svou taktiku radikálně přepracovala a začala obyvatele tábora zpovídat o všem možném jen ne o předmětu svého zájmu. Dotazovala se na postoje ke vzdělávání, sociální stratifikaci Japonska, kriminalitu mladistvých atd. Její strategie byla úspěšná. Vedle hlavního cíle získat prrístup mezi zkoumané získala různé informace o jejich sociálním životě a rovněž potvrdila svou roli vědeckého pracovníka (Wax R. 1957, s. 134-35).

$\mathrm{V}$ mém př́padě vedly neúspěchy s dotazováním $\mathrm{k}$ rezignaci na jakékoli strukturované rozhovory a ke snaze výzkumnickou roli spíš potlačovat. Přednost dostaly neformální a nestrukturované rozhovory. První typ odkazuje k nezávazným konverzacím, jejichž účelem je se s někým seznámit a také získat v neznámém sociálním prostředí orientaci. Oč je tento postup př́ijemnější při jeho provádění, o to namáhavější a pracnější je následné zaznamenávání poznámek. Naproti tomu nestrukturované dotazování má parametry rozhovoru, kdy si jsou obě strany vědomi, že probíhá interview. Nestruk-

5 Mezi jinými to byly např́íklad: dětství a výchova; vztahy na základní škole (učitelé, žáci); suma všech kontaktů s majoritou a jejich charakter; subjektivně pocitované nedostatky při komunikaci s př́íslušníky majority; uchovávání tradiční romské kultury; príichod do Čech (pra/rodiče); postoje vůči Čechům a jejich kultuře, stereotypy; jazykové kompetence, užívání romštiny, „východňárský“ přízvuk.

6 O. Hejnal se domnívá, že polo/strukturované rozhovory mohou být pro členy stigmatizované skupiny nevyhovující, jelikož formou připomínají policejní výslech (2012, s. 146, pozn. 16).

7 Terénní deník (5. 6. 2012). 
turovanost tkví v tom, že výzkumník sleduje určitý plán, ale dotazovanému nechává absolutně volný prostor k odpovědím (srov. Bernard 2006, s. 211-12).

Navzdory diskutované nevhodnosti strukturovaných technik sběru dat je přístup R. Waxové inspirativní i při výzkumu Romů. Jeho podstatou je sestavení sady témat a otázek, které se nemusí týkat vlastní výzkumné otázky a přitom zní náležitě „vědecky“. Smyslem je respondenty co nejvíce rozhovořit, a proto by měly mít ryze nekonfliktní charakter. ${ }^{8} \mathrm{~V}$ případě Romů se nabízí např́klad sběr tradičních kuchařských receptur, lidové slovesnosti, „muzikologický" výzkum, oslavy spojené s životními milníky (křtiny, pohřeb). Po vybudování důvěry lze přikročit k otázkám, které nás skutečně zajímají.

\section{VYSVĚTLENÍ VÝZKUMNÍKOVY ROLE}

Ve fázi získávání přístupu je určující, jak bude badatel svůj výzkum navenek. Co informantům sdělí o účelu, postupech, př́ípadně i benefitech. Úplné „odtajněni“ není často možné, ani žádoucí podobně jako $\mathrm{v}$ běžné sociální interakci. (Hammersley; Atkinson 2007, s. 42). Mnohdy je třeba vyčkat až do okamžiku, kdy si u informantů vybudujeme dostatečný rapport. Zároveň se co nejvíce vyvarovat klamání - nejen $z$ etických důvodů, ale také kvưli předcházení nepř́ijemným komplikacím v pozdějších fázích výzkumu (tamtéž, s. 57). Bez řádně propracovaného osvětlení vlastní přítomnosti si výzkumník zajistí př́istup jen s obtížemi. Lidé potřebují slyšet něco, co jim dává smysl a co v ideálním případě činí $\mathrm{z}$ výzkumníka důvěryhodnou osobu. Zároveň se nezajímají o detailní popisy výzkumu. (Feldman et al. 2003, s. 26-27).

Vzhledem k minimální historické zkušenosti Romů s terciárním stupněm vzdělávání jsem se nepokoušel vysvětlovat, že jsem doktorandem sbírajícím data pro svou dizertační práci. Zvolil jsem roli „naivního studenta“, který musí do školy sepsat práci na již zmiňované téma, „proč spolu Češi a Cigáni nemluví, obvykle s dodatkem „a to v knížkách nenajdu“. Jistou chybou bylo zveřejnění oboru, který v daném sociálním prostředí neposkytoval žádné hmatatelné vodítko. Snazší cestou by bylo nevyvracet domněnku, že jsem studentem „sociální školy“ na praxi, nebot’ jsem v této fázi často docházel do nízkoprahového klubu. To jen potvrzuje skutečnost, že zveřejnění vlastní role neznamená automaticky její přijetí. Lidé mají tendenci přiřadit roli podle svého sociálního prostředí a zkušeností (Hammersley; Atkinson 2007, s. 65). Později mi byla $\mathrm{v}$ souvislosti s doučováním dětí přidělena role učitele.

Dřivější generace antropologů ve svých reflexích terénu po-

8 Podle M. Jakoubka je př́mo žádoucí předkládat témata $\mathrm{k}$ rozhovoru. Nikoli však taková, která výzkumníka přímo zajímají, ale především taková, která informanty co nejvíce rozhovoří. Osobní konzultace (17. 10. 2013).

9 M. Jakoubek mi rovněž rozmluvil původní záměr distancovat se od školy a prezentovat se jako výzkumník, který na toto téma píše knihu. Osobní konzultace (30. 3. 2013). ukazovaly na fyzickou a intelektuální izolaci badatele, která $\mathrm{v}$ dnešním globalizovaném světě již takovým problémem nebývá. Aktuálnější se stala otázka blízkosti vztahu k informantům, kterou starší generace zaujímající roli „profesionálního cizince“ nereflektovaly. Zdá se, že dnešní antropologové cítí bližší sympatie vůči studovaným lidem, a proto se je snaží co nejméně vyrušovat (Watson 1999, s. 12-14). Z téhož důvodu jsem se snažil vyvarovat termínu výzkum, který přinejmenším v kontextu romské lokality zbytečně odkazuje na panující mocenskou nerovnováhu. Namísto toho jsem zdůrazňoval, že jsem se přišel naučit.

\section{STRATEGIE ZÍSKÁNÍ PŘÍSTUPU}

Druhá část příspěvku představuje (chronologicky) proces získávání přístupu mezi obyvatele romské čtvrti. Při etnografickém výzkumu badatel netuší vždy zcela přesně, jaké informace potřebuje, ani kdo mu je bude moci poskytnout. Nehledá konkrétní jedince, ale ty, kteří budou ochotni ke spolupráci. Navzdory střízlivému očekávání, že nepůjde o jednoduchý podnik, jsem mnohokrát stál blízko rozhodnutí vše vzdát. $\mathrm{V}$ tomto směru doporučuji držet se názoru A. Beattyho, podle něhož „V terénu dříve či později stejně narazíme na ty správné lidi“ (1999, s. 79). S určitou nadsázkou lze říci, že kolik je jedinců kolem nás, tolik máme možností získat př́stup.

\section{BYDLENÍ}

Zúčastněné pozorování je metodou, při které se výzkumník snaží podílet na každodenních aktivitách sledované populace a dlouhodobě s ní žít. Jako nezákladnější strategie se jevilo nalézt si menší byt někde v širším centru romské čtvrti. Žít přímo v jejím jádru, kam jsem se v minulosti vydával se staženým hrdlem a opouštěl s nevýslovnou úlevou, jsem si netroufal. Také jsem předpokládal, že na základě pozorování života v domě a jeho okolí získám představu o fungování čtvrti a př́íležitost seznámit se $\mathrm{s}$ některým $\mathrm{z}$ romských sousedů. V kontextu hledání prrístupu je povinnou četbou etnografie Street Corner Society, jejímž autorem je W. Whyte (1993). Zatímco studie pojednávající o životě v italském slumu v Americe 30. let 20. století nevzbudila prŕlišný ohlas, připojený apendix (od 2. vydání) z ní učinil „klasiku“. Autor v něm zcela otevřeně líćí všechny své chyby a přešlapy, kterých se při hledání informantů dopustil (1993, s. 279-317).

Whyte se v rámci svého výzkumu ubytoval u seriózní rodiny vlastnící restauraci, která jej záhy přijala jako člena rodiny (tamtéž, s. 294-98). Podle jeho vzoru jsem prostřednictvím pracovníků neziskové organizace hledal podnájem u některé místní rodiny, která by uvítala další př́ijem. Na oplátku mi její členové mohli usnadnit vstup do terénu. Zásadní problém představovala otázka, jak by na život $\mathrm{v}$ romské rodině reagovala partnerka (s ročním dítětem). Záležitost se vyřešila sama, když mi obec nabídla garsoniéru v těsné blízkosti centra lokality. K získání obecního bytu je zapotřebí splňovat dvě 
podmínky 1) minimálně pětiletý trvalý pobyt a 2) absence finančních závazků u obce, avšak „neproblémové“ osoby mohou obdržet byt na základě výjimky.

Uspokojení ze štastné náhody trvalo jen krátce. Dům svůj někdejší věhlas jako „nejhorší z nejhorších“ ztratil již před lety, kdy obci došla trpělivost a nové nájemníky si začala pečlivě vybírat. Dnes v něm žijí jen dvě integrované romské rodiny. Vzhledem k vysokému věku svůj byt prakticky neopouští, a proto nebylo možné získat přistup alespoň k nim. Navzdory tomu, že se bydlení v blízkosti lokality jako strategie získávání přístupu neosvědčilo, ve zpětném pohledu se jeví jako dobrá volba. Představuje přijatelný kompromis mezi snadnou přístupností „terénu“ a výzkumníkovou autonomií potřebnou ke studiu, zapisování poznámek i odpočinku od informantů.

\section{KONFLIKT V TERÉNU}

Ke zklamání z nevhodně zvoleného místa ubytování se záhy přidal nepř́ijemný konflikt, po němž hrozilo, že výzkum skončí dříve, než začal. Během druhého týdne pobytu v terénu se mi podařilo provést rozhovor s místním romským intelektuálem Rumcajsem. Tento absolvent střední školy byl vychováván $\mathrm{v}$ dětském domově, odkud si jej v útlém věku osvojila zámožná česká rodina. Věnoval se práci s mládeží, dokud kvůli neshodě se sourozencem od rodiny neodešel. Jak sám podotkl, z Čecha se stal zpátky Cigánem a své schopnosti začal využívat $\mathrm{k}$ méně bohulibým aktivitám. $\mathrm{Z}$ mého pohledu představoval ideálního (klíčového) informanta orientujícího se stejně bezpečně $\mathrm{v}$ mém světě i světě Romů, který navíc o můj výzkum projevoval zájem.

Několik dní po našem rozhovoru jsme se potkali na ulici. Obořil se na mě, zda je pravda, že jsem tu už kdysi prováděl výzkum a o místních Cigánech napsal tolik špatného. Když jsem se se zděšením zeptal, kde se to dozvěděl, sdělil mi, že mu vše vyložila místní romská terénní sociální pracovnice. Ihned mě napadlo, že pokud o mě dotyčná pracovnice se svým nesporným vlivem na místní Romy šírí takové informace, je vážně ohrožena nejen má studie, ale i bezpečnost. Rumcajs mě jen odbyl, že tady jsem prostě skončil. V rozčilení, že kvůli pomluvám přicházím o slibně se vyvíjející výzkum, jsem se ihned vydal do kanceláře dotyčné. Začal jsem se rázně vyžadovat vysvětlení a měl tak možnost se prvně v životě přesvědčit o př́islovečném „cikánském temperamentu“.

Ještě nikdo mi v životě tak nevynadal. Dotyčná mi naštěstí vytýkala i údajné nedostatky, které dokazovaly, že ne všemu porozuměla. Například zmínky o rituální nečistotě interpretovala ve významu „Cigáni jsou špíny” ${ }^{10}$. Nejspíš jen díky tomu se mi podařilo jí přesvědčit, že studii přinesu, abych věci uvedl na pravou míru. K mému překvapení po mém návratu zaujala mnohem konstruktivnější polohu a předkládala návrhy, jak by se závěry studie daly formulovat výstižněji. $\mathrm{Na}$ oplátku jsem uznal, že viděno očima Romů se některé části mohly jevit jinak, než byly zamýšleny. Podařilo se nám

10 Terénní deník (15. 6. 2012). uzavřít příměří stvrzené nabídkou, abych jí občas doprovázel do terénu.

Kvůli konfliktu jsem byl mnoho dalších týdnů paranoidní, nebot jsem netušil, jak daleko se neblahá zpráva roznesla. Psychicky jsem se snažil obrnit zkušenostmi předních badatelů, kteří přestáli mnohem závažnější katastrofy. P. Bourgois během výzkumu mezi dealery cracku urazil negramotného drogového bosse, když jej z nevědomosti nutil číst novinový článek. Kvưli reálným obavám o své bezpečí se pak musel řadu měsíců skrývat, než událost upadla v zapomnění (2003, s. 19-27). S. Venkatesh působící rovněž v ghettu kompromitoval své respondenty tím, že v dobré víře informoval o jejich neoficiálních př́jmech správkyni budovy. Ta je následně „zdanila“ aniž by zatajovala, kdo je prozradil. Pokračovat ve výzkumu navzdory mrazivým vztahům s informanty jej přimělo jen to, že stál těsně před jeho dokončením (2008, s. 196-206).

Přesto jsem se obav z možných komplikací nezbavil již nikdy. Také $\mathrm{z}$ tohoto důvodu jsem začal uvažovat o skrytější formě výzkumu, abych zbytečně neodkazoval $\mathrm{k}$ předchozímu působení ve čtvrti. Od úplného ukončení mě odrazovala pouze představa vynakládání času a energie nutných $\mathrm{k}$ přesunu výzkumu. Na druhou stranu mě událost přiměla přehodnotit jeden $\mathrm{z}$ myšlenkových pilírů výzkumu. Lze na ní ilustrovat základní problém zkoumání romských populací, jímž je problematické uchopení předmětu výzkumu. Je přiléhavější referovanou skupinu pojímat jako sociální skupinu či etnickou? ${ }^{11}$ Domnívám se, že vhodnost těchto konceptů v mnohém závisí na povaze výzkumné otázky.

\section{POUČENÍ Z KONFLIKTU: ROMSKÁ ETNICKÁ IDENTITA}

V historii patřili Cikáni/Romové mezi endogamní populace, které úspěšně konkurovaly zavedeným profesím, jejichž představitelé vedli usedlý způsob života. Jejich ochota přesunovat se za zdrojem obživy a věnovat se „okrajovým“ př́ležitostem jim umožňovala vyplňovat mezery v ekonomických systémech hostitelských společností (Gmelch 2008, s. 344). Romové se dodnes orientují na využívání nedokonalostí a mezer v dominantním systému (tamtéž s. 371-72) a díky tomu jsou relativně často s majoritní společností v kontradikci. Některým se podařilo prosadit ve volných a majoritou respektovaných nikách. $\mathrm{V}$ minulosti to byli například hudebníci nebo handlíri, dnes dovední řemeslníci, asistenti na školách, sociální pracovníci (srov. Hübschmannová 1999). Z nich se postupně vyprofilovala ekonomicky a později i sociálně odlišná skupina, jež má pro své přijímání majoritní kultury uvnitř romské populace hanlivé označení „pogadžovaní“. ${ }^{12}$

11 Odkazy ke konkrétním textům věnujícím se této problematice by zaplnily zbytek textu. Doporučuji nahlédnout do bibliografického přehledu Marka Jakoubka (2008) o dosavadní cikánologické překladové literatuře vydané $\mathrm{v}$ češtině.

12 Termín gadžo označuje ne-romské, „bílé”, majoritní obyvatelstvo a je v různých obměnách užívaný po celém světě. 
Romy jsem chápal především jako sociální skupinu. Předpokládal jsem, že "pogadžovaní“ nechtějí mít se zbytkem romské populace za žádných okolností nic společného, nebot’ se plně socializovali do majoritní společnosti. Popisovaný konflikt ukazuje, jak může dojít k mobilizaci silného pocitu sounáležitosti, který sociální rozdíly popírá. „Pogadžovaná“ sociální pracovnice se za běžných okolností od místních Romů distancuje. V okamžiku, kdy se jim ze strany Čechů děje křivda či bezpráví, se staví na jejich stranu a dokonce se s nimi identifikuje „my jsme taky Cigáni, co vy o tom můžete vědět!“13. Přes obrovské socio-ekonomické změny, které Romy - zejména „pogadžované“ - přiblížily majoritě, stále přetrvávají jako výrazně odlišná populace (srov. Barth 1969, s. 32-33). V rámci výzkumu bariér $\mathrm{v}$ interakci jsem se proto rozhodl zaměřit nejen na marginalizované Romy, kteří jsou s Čechy ve více či méně latentním konfliktu, ale zohledňovat také „integrovanou“ část populace. Jak již bylo uvedeno, začal jsem Romy ve svém výzkumu nahlížet jako etnickou skupinu, jako celek.

\section{VSTUP PROSTŘEDNICTVÍM VRÁTNÉHO}

Merton jako nejefektivnější vstup do „komunity“ doporučuje kontaktovat osobu s vysokým statusem, prestiží či autoritou (Merton 1947, s. 34). V odborném žargonu se taková osoba označuje jako vrátný (gatekeeper). Vstup přes vrátné bývá snazší, nebot zajištují výzkumníkovu legitimitu u lidí, mezi které se snaží proniknout (Feldman et al. 2003, s. 31). Bez nich není myslitelný (oficiální) výzkum především $\mathrm{v}$ rámci institucí, ale důležití mohou být i v jiných kontextech. Např́klad již zmiňovaný Whyte se seznámil s klíčovým informantem (Doc) díky sociálním pracovníkům komunitního klubu. Nicméně doporučuje obrátit se na (katolickou) církev či lokálního politika (1993, s. 290).

Jelikož se v lokalitě žádný romský politik nevyskytoval, pokoušel jsem se ke zprostředkování kontaktu využít místní farnost. Doufal jsem nalézt rodinu, která by asistenci začínajícímu výzkumníkovi chápala jako určitou křest̉anskou „povinnost“. Vycházel jsem z mylného úsudku, že pokud Romové křtí své děti, odmítají antikoncepci a svým mrtvým vypravují křest̉anské pohřby, musí alespoň některá rodina navštěvovat kostel (srov. Jakoubek 2004, 178-181).

Po několika dnech, kdy jsem se bez úspěchu snažil faráře kontaktovat, se mi dostalo rady, abych svých pokusů zanechal. Vztahy mezi místními Romy a církví jsou více než napjaté, nebot farář odmítl rodičům, kteří žijí v rozporu s Desaterem, křtít děti. Nikdo z místních za ním proto nedochází a křtít se jezdí do okresního města. Navzdory mým zkušenostem není získávání prrístupu prostřednictvím církve nutno zavrhovat. Nicméně je třeba počítat $s$ tím, že úspěch závisí na osobnostních charakteristikách vrátného. (Zůstává otázkou, nakolik by byla strategie úspěšná $\mathrm{v}$ př́padě jiné křestanské církve).

13 Terénní deník (15. 6. 2012).

\section{SDÍLENÍ PROSTORU}

Obdiv v kontextu této studie vyvolává lehkost, s jakou autor klasické studie Tally's Corner E. Liebowov (2003) pronikl mezi obyvatele černošské čtvrti. Počátkem 60 . let 20. století prováděl ve Washingtonu výzkum mužů s nízkými příjmy. První den v terénu, když pozoroval zatýkání nějaké ženy, zapředl s poblíž postávajícím mužem rozhovor trvající několik hodin. Druhý den se seznámil se svým klíčovým informantem (Tally) při diskuzi s několika opilci na téma „alergie na psy“. S ním pak strávil další hodiny povídáním a popíjením kávy v kavárně. Již na konci druhého dne nabyl pocitu, že zde není úplným cizincem. Během prvního měsíce se seznámil s řadou dalších lidí, po třech měsících už mezi nimi měl několik dobrých přátel, a po čtyřech měsících volně chodil po jejich domácnostech v jakoukoli denní dobu (2003, s. 151-166). V Liebowě př́padě se snoubí nesporná sociální inteligence, znalost daného prostředí (do dospělosti vyrůstal v černošských čtvrtích) a skutečnost, že nebyl „úplný běloch“ (Žid).

$\mathrm{V}$ jeho prospěch hrála také úroveň občanské vybavenosti. $S$ lidmi se seznamoval v kavárně, chodil na snídaně a obědy do místního bufetu, navštěvoval zdejší bary, kulečníkové herny atd. V sociálně vyloučených lokalitách bývá občanská vybavenost obvykle na velmi nízké úrovni, na což jsem při hledání př́stupu neustále narážel. Nedokázal jsem nalézt platformu, jak být fyzicky př́tomen na témže místě a v dostatečné blízkosti místních Romů, a zároveň nepůsobit rušivě. Frustrující na nemožnosti navázat s někým bližší vztah bylo to, že potenciálních informantů byly plné ulice.

$\mathrm{V}$ prvních týdnech jsem se snažil navštěvovat prostory, které nabízely príležitost alespoň k pozorování: koupaliště a rybníky, parky, místní večerky, dětská hřiště, knihovnu (s internetem), hojně jsem se procházel po čtvrti. Postupně začalo být zřejmé, že pouhá př́ítomnost $\mathrm{v}$ terénu nestačí, a bude třeba mnohem aktivnější přístup. Zároveň jsem se zdráhal využít př́ležitosti v podobě místní romské hospody. Přijít mezi neznámé lidi, upíjet pivo a s někým případně zapříst rozhovor neodpovídá mému naturelu. S myšlenkami na nedávný konflikt mi to nepřišlo ani bezpečné. Nakonec jsem objevil záminku sledovat zápasy českého týmu během fotbalového mistrovství na místní TV. Po skončení šampionátu jsem náhradní důvod již nenašel.

Druhou potenciální příležitost jsem odhalil ve zdejší sázkové kanceláři, kterou navštěvovala řada Romů. Nechal jsem si za tímto účelem vysvětlit principy sázení na sportovní zápasy, ale bez jakéhokoliv úspěchu (nemluvě o finančním). Romové zde jen výjimečně setrvali déle než pár minut. Rychle zkontrolovali tažená čísla, př́padně si vsadili znovu a zase odešli. Sázky na sportovní utkání, k jejichž výběru je třeba mnohem více času, je nezajímaly. Nutno dodat, že docházení do sázkové kanceláře jsem se nevěnoval př́iliš intenzivně, nebot' se mezitím jako (dočasně) úspěšná ukázala jiná strategie. Při soustavnějším provádění by pravděpodobně mohla být úspěšná, nebot’ sázková kancelář v sobě spojuje dva základní předpoklady, jimiž jsou fyzická blízkost a provádění téže činnosti. 


\section{SPOLEČNÉ ZÁJMY}

Nejpravděpodobnější šance na získání přístupu jsem vzhledem k věkové blízkosti očekával u mužů mezi 20-30 lety. V již zmiňované etnografické studii S. Venkateshe Gang Leader for a Day (2008) autor popisuje, jak se na počátku vydal s několika dotazníky v batohu do jedné z nejnebezpečnějších oblastí Chicaga. Okamžitě byl zajat jako špion nepřátelského gangu a po několik hodin zůstal jeho zajatcem. Zásluhou nerozvinutého pudu sebezáchovy se po svém propuštění do oblasti vrátil znovu, což vzbudilo respekt a zájem vůdce gangu (tamtéž, s. 10-25). V žádném případě jsem na podobná dobrodružství nepomýšlel, nicméně ideálem bylo nalézt spojení na nějaké neformální sociální uskupení místních mladíků („partu“).

Do svého úsilí jsem zapojil i pracovníky neziskové organizace a požádal je, aby mi vytipovali nějakého šikovného mladíka $s$ určitou autoritou. Když nikoho takového nedokázali identifikovat, přisuzoval jsem to skutečnosti, že s požadovanou kategorií pravděpodobně nepřichází do styku. Později, když jsem již pronikl mezi místní, se mi dostalo částečného vysvětlení, že aktivní členství v „partě“ končí okamžikem narození prvního dítěte. U mladých mužů to bývá nezřídka před osmnáctým rokem života, u dívek ještě dřive. Jinak řečeno, „party“ se rozpadají mnohem dříve, než u majority. Svou roli nepochybně hraje i skutečnost, že Romové nevytvářejí uskupení na základě společných zájmů, věku či zaměstnání. Druží se především na př́ibuzenském principu (srov. Budilová; Jakoubek 2007 či Jakoubek; Budilová 2009).

Ve snaze nalézt svého informanta jsem rovněž doprovázel sociální pracovníky při jejich obchůzkách po rodinách. Přesto - nebo možná právě proto - jsem zůstával součástí vnějšího systému. Rozhodl jsem se zkusit získat přistup bez vrátného. Jay MacLeod ve své etnografii Ain't No Makin' It porovnává očekávání vůči budoucímu povolání dvou skupin mladíků (černoši a běloši) na jednom americkém sídlišti začátkem 80 . let 20. století. Na počátku jeho úspěšného proniknutí stála účast na realizaci podpůrného sociálního programu pro místní děti. Skutečný průlom zaznamenal až díky hraní basketbalu s jejich staršími bratry (2004, s. 270-302).

Výzkumníkovo určité sportovní nadání nemusí znamenat vítězství. Hledání informantů se do určité míry podobá „dobýváni“" partnera. Zatímco je výzkumník potřebuje, z jejich strany je ve fázi hledání přístupu o takovou pozici zájem jen výjimečně (Feldman et al. 2003, s 5). Z tohoto pohledu musí výzkumník prokázat $\mathrm{v}$ dané aktivitě jistou virtuozitu, a navíc v oblasti, která je v daném prostředí oceňována. To však nebyl můj prŕpad. Nevynikám ve sportovní činnosti číslo jedna, jíž je bezpochyby fotbal. Stejně tak v boxu ani v jiných bojových sportech, které zde mají vysokou prestiž. Naopak aktivity typické pro členy střední třídy - plavání, jízda na horském kole, lyžování - zde neměly žádnou váhu a nedalo se jich v rámci získávání prrístupu nijak využít.

Během dalšího působení v terénu se ukázalo, že postrádám jakékoli praktické dovednosti upotřebitelné $\mathrm{v}$ daném prostředí, jimiž bych mohl zaujmout. Smysl pro humor, na který jsem rovněž sázel, nebot mi při jiných výzkumech pomáhal respon- denty naklonit, se ukázal jako do značné míry nekompatibilní. Rozhodně tím nelze říci, že by humor místních byl prostší, spíše bylo náročné se jim $\mathrm{v}$ tomto směru vyrovnat. Jako další záminky jsem se pokusil využít závady na svém vozidle. Auto jsem zavezl do místní autodílny, jejímiž majiteli jsou Češi, ale obvyklé zákazníky tvoří romští mladíci. Oprava byla komplikovanější než se zdálo, což umožňovalo docházet do dílny na inspekci a nezávazně hovořit se všemi přítomnými. Auta tvoří důležitou součást lokální ekonomiky a „vědění”. Mladíci prakticky nedělali nic jiného, než že porovnávali jejich značky a typy; ceny, výkony a přednosti; mluvili o součástkách, opravách, „tunningu“; nákupech, převážení a prodejích. Jelikož jsem v tomto směru pro ně nebyl rovnocenným partnerem pro diskuzi, přestali mě - přes počáteční zájem z jejich strany - do svých debat zahrnovat.

Navzdory neúspěchům se mi podařilo identifikovat oblasti, kde by mohli uspět jiní. Nalezení „společné řeči“ by usnadnila znalost tance nebo hry na hudební nástroj, či alespoň kulečníku. Vítaná, ovšem v praxi obtížně dosažitelná, by byla zběhlost $\mathrm{v}$ nějakém řemesle, díky které by bylo možno pomýšlet na práci v romské pracovní skupině. Naproti tomu se mezi výzkumníky nepochybně najde odborník na IT technologie, který by měl řadu dveří otevřených. Prakticky v každé domácnosti se vyskytuje vysloužilý, ale hojně využívaný počítač kvůli připojení na internet, respektive kvưli facebooku a skypování. Výhodu by měl antropolog s rybářskou průpravou, který by se svými informanty mohl trávit dlouhé hodiny rozprávěním u místních rybníků.

\section{MOŽNOSTI PŘÍSLUŠNÍKA STŘEDNÍ TŘÍDY}

Po neúspěšných pokusech získat přístup prostřednictvím společných zájmů přicházelo v úvahu jediné. Poskytnout Romům něco, co je v jejich okolí nesnadno dostupné. Na konci léta se mi naskytla možnost připravovat jednoho studenta střední školy k opravným zkouškám. Byla to vysloveně ideální př́ležitost, jelikož mladík byl inteligentní, měl nadstandardní přehled o veškerém dění v lokalitě, a jeho rodina patřila ke zdejší elitě. Po několika lekcích mě rodiče začali zvát na návštěvy, dokonce jevili zájem o můj výzkum a ochotně se mnou rozmlouvali. Nadějný vývoj se přerušil v okamžiku, kdy mladík nesplnil první zkoušku, a s tím zanikly důvody k doučování i pozvánkám na návštěvu.

Motivován dílčím úspěchem jsem se krátce nato přihlásil jako dobrovolník na doučování v jedné neziskové organizaci. Uběhl měsíc, aniž bych s rodiči dvou sourozencủ, které jsem doučoval, došlo k navázání nějakého bližšího vztahu. Zájem o můj výzkum byl z jejich strany čistě formální. Průlom nastal v okamžiku, kdy jsem při příležitosti blížící se rodinné oslavy rodičům nabídl, že je odvezu svým autem na nákup do okresního města. ${ }^{14}$ Cena za odvoz byla zhruba poloviční

14 Za tento postřeh děkuji Laco Touškovi, který se o výhodách vlastního automobilu přesvědčil při svém výzkumu v romských osadách na Slovensku. Osobní konzultace (17. 10. 2013). 
až čtvrtinová oproti ostatním „dopravcům” v lokalitě, jelikož její součástí nebyla žádná provize. $\mathrm{V}$ rámci reciprocity ústila příznivá cena $\mathrm{v}$ pozvání na oslavu, která následně otevřela cesty k vybudování rapportu. Postupně se ze mě stal rodinný dopravce a konzultant při jednání s úřady, výjimečně i záložna, vděčný posluchač a host na různých návštěvách a oslavách po celé rodině, ale také přítel.

\section{SHRNUTÍ}

Zúčastněné pozorování s sebou přináší problém, jak přirozeně proniknout do sociálního světa lidí, o které máme zájem. Badateli, který má zkušenosti s terénními výzkumy a/nebo je $\mathrm{v}$ daném prostředí zběhlý, může tento úkol zabrat pouhý den (srov. Liebow 2003). Mnohem častěji k němu dochází v řádu týdnů a měsíců, jak dokládá tento příspěvek. K získání přístupu došlo zásluhou neziskové organizace, která jako vrátný garantovala výzkumníkovu důvěryhodnost př̀i provádění doučování. Poskytování levného odvozu spadá spíše do oblasti budování rapportu, ale je zřejmé, že obě fáze od sebe nelze jasně oddělit. Na základě vlastních zkušeností si dovoluji navrhnout několik možných strategií, jak si zajistit př́stup mezi obtížně př́stupnou skupinu jako jsou Romové. Do značné míry pokrývají kontinuum př́stupů na škále od účasti po pozorování.

Nejsnazší a nejméně jistou cestou je spoléhat na existenci osvícené osoby, která by za zajímavou považovala samotnou participaci na výzkumu. Její úlohu lze definovat jako průvodce nebo „sponzor“, jehož lokální autorita či prestiž usnadňuje výzkumníkovi pohyb v terénu. Předobrazem této postavy je Whytův informant Doc, který si přál, aby se o realitě života ve slumu dozvěděla veřejnost (Whyte 1993, s. 293). Své pochybení spatřuji $\mathrm{v}$ prrílišném lpění na této variantě, která zbytečně brzdila zkoušení jiných cest. Informanta nemusí motivovat pouze intelektuální či filantropické důvody, ale také ryze praktické. Blízký vztah se zástupcem majority může slibovat různé zisky v materiální (alkohol, cigarety, dárky dětem) i symbolické podobě (zvýšení prestiže) nebo zajištění služeb (doučování, IT dovednosti). Lze sem zařadit všechny charakteristiky výzkumníka, které z něj činí vyhledávaného společníka (sportovní nadání, smysl pro humor). Klíčová je v tomto bodě identifikace "poptávky“ a pečlivé zhodnocení možností „nabídky“.

Jinou možností je soustředit se na roli vnějšího pozorovatele a provádět formální sběr dat. Diskutované nevhodnosti strukturovaných technik sběru dat při výzkumu Romů se lze vyhnout př́stupem realizovaným $\mathrm{R}$. Waxovou. Jeho podstatou je překonávání nedůvěry respondentů prostřednictvím diskuze atraktivních témat. Tuto variantu lze doporučit introvertně založeným či „nepraktickým“ badatelům, kteří z jakýchkoli důvodů aktivnější participaci odmítají. Nevýhodou je nesnadná identifikace dostatečně přitažlivých témat a jistá obtrusivita při přesvědčování respondentů $\mathrm{k}$ účasti. Kromě nezbytného štěstí je podle mého názoru ve všech prrípadech klíčová identifikace bonusů, které by informanty motivova- ly ke spolupráci na výzkumu. At’ už je to zveřejnění podmínek života dané „komunity“, materiální zisky, zvýšení osobní prestiže, zajištění zábavy či pouhá možnost se vypovídat. Podstatou interakce s informanty je reciproční výměna informací na jedné straně a určitých zisků na straně druhé.

\section{LITERATURA}

Barth, Fredrik, ed. (1969): Ethnic Groups and Boundaries. The Social Organization of Culture Difference. Boston: Little Brown and Company.

Beatty, Andrew (1999): On Ethnographic Experience: Formative and Informative. In: Watson, C. William, ed., Being There. Fieldwork in Anthropology. London: Pluto Press, s. 74-97.

Bernard, H. Russell (2000): Social Research Methods: Qualitative and Quantitative Approaches. Thousand Oaks: Sage Publications.

Bernard, H. Russell (2006): Research Methods in Anthropology. Qualitative and Quantitative Approaches. Lanham: AltaMira Press.

Bourgois, Philippe (2003): In Search of Respect. Selling Crack in El Barrio. Cambridge: Cambridge University Press.

Budilová, Lenka; Jakoubek, Marek (2006): Genealogická metoda a její použití při výzkumu v cigánské osadě. Akta 2006 0/1, s. 145-158.

Budilová, Lenka; Jakoubek, Marek, eds. (2007): Cikánská rodina a príbuzenství. Ústí nad Labem: Dryada.

Cohn, Werner (2009): Cikáni. Praha: Slon.

Dewalt, M. Kathleeen; Dewalt, R. Billie; Wayland, B. Coral (1998): Participant Observation. In: Bernard, H. Russell, ed., Handbook of Methods in Cultural Anthropology. Wallnut Creek: Altamira Press, s. 259-301.

Eriksen, H. Thomas (2001): Small Places, Large Issues. An Introduction to Social and Cultural Anthropology. London: Pluto Press.

Eriksen, H. Thomas (2012): Etnicita a nacionalismus. Antropologické perspektivy. Praha: Slon.

Feldman, S. Martha; Bell, Jeannine; Berger T. Michele (2003): Gaining Access. A Practical and Theoretical Guide for Qualitative Researchers. Walnut Creek: AltaMira Press.

Fetterman, M. David (1998): Ethnography. In: Bickman, Leonard; Rog, J. Debra, eds., Handbook of Applied Social Research methods. Thousand Oaks: Sage Publications, s. 473 - 508.

Fraser, Angus (2002): Cikáni. Praha: Nakladatelství Lidové noviny.

Gmelch, B. Sharon (2008): Skupiny, které nechtějí být začleněny: Cikáni a jiné řemeslnické, obchodnické a zábavu poskytující skupiny. In: Jakoubek, Marek, ed., Cikáni a etnicita. Praha: Triton, s. 344-380.

Hammersley, Martyn; Atkinson, Paul (2007): Ethnography. Principles in practice. Taylor and Francis e-Library.

Hejnal, Ondřej (2012): Antropologův den mezi „klienty represe“: Zúčastněné pozorování bezdomovců ve středně velkém městě. Antropowebzin 3/3, s. $141-152$.

Hübschmannová, Milena (1999): Od etnické kasty ke strukturovanému etnickému společenství. In: Kolektiv autorů, Romové v České republice (1945-98). Praha: Socioklub, s. 115-136.

Jakoubek, Marek (2004): Romové - konec (ne)jednoho mýtu: tractatus kulturo(mo)logicus. Praha: Socioklub.

Jakoubek, Marek (2008): Bibliografický přehled překladové (odborné) cigánologické literatury vydané v ČR a SR po roce 1989. Antropowebzin 2/3, s. $45-57$.

Jakoubek, Marek; Budilová, Lenka, eds. (2009): Cikánské skupiny a jejich sociální organizace. Brno: CDK.

Ladányi, János; Szelényi, Iván (2006): Patterns of Exclusion: Constructing Gy psy Ethnicity and the Making of an Underclass in Transitional Societies of Europe. New York: Columbia University Press.

Lareau, Anette (1996): Common Problems in Field Work: A Personal Essay. In: Lareau, Annette; Shultz, Jeffrey eds., Journeys Through Ethnography. Realistic Accounts of Fieldwork. Boulder: Westview Press, s. 195-236.

Liebow, Elliot (2003): Tally's Corner. A Study of Negro Streetcorner Men. Lanham: Rowman and Littlefield Publishers.

Lewis, Oscar (1998): The Culture of Poverty. Society, 35 (2), s. 7-9.

MacLeod, Jay (2004): Ain't No Makin' It. Aspirations and Attainment in a Low-Income Neighborhood. Boulder: Westview Press. 
Marcus, E. George (1997): The Uses of Complicity in the Changing Mise-enScène of Anthropological Fieldwork. In Representations, No. 59, Special Issue: The Fate of "Culture": Geertz and Beyond, s. 85-108.

Mareš, Petr (2000): Chudoba, marginalizace, sociální vyloučení. Sociologický časopis, XXXVI (3), s. 285 - 296.

Mareš, Petr, Sirovátka, Tomáš (2008): Sociální vyloučení (exkluze) a sociální začleňování (inkluze) - koncepty, diskurz, agenda. Sociologický časopis, XLIV (2), s. 271-294.

Merton, K. Robert (1947): Selected Problems of Field Work in the Planned Community. American Sociological Review, Vol. 12, No. 3, s. 304-312.

Moravec, Štěpán (2009): Nástin problému sociálního vyloučení romských populací. In: Hirt, Tomáš; Jakoubek, Marek, eds., Romové v osidlech sociálního vyloučení, Plzeň: Aleš Čeněk.

Venkatesh, Sudhir (2008): Gang Leader for a Day. A Rogue Sociologist Takes to the Streets. New York: Penguin Press.

Pelikán, Vojtěch (2011): Nezemědělská povaha životního zpo̊sobu spišských Romů: Stereotypy a realita. Antropowebzin 3/3, s. 163-170.

Wax, H. Rosalie (1957): Twelve Years Later: An Analysis of Field Experience. American Journal of Sociology, Vol. 63, No. 2, s. 133-142.
Watson, C. William, ed. (1999): Being There. Fieldwork in Anthropology. London: Pluto Press.

Wax, L. Murray; Wax, H. Rosalie (1980): Fieldwork and the Research Process. Anthropology \& Education Quarterly, Vol. 11, No., s. 29-37.

Whyte, F. William (1993): Street Corner Society. The Social Structure of an Italian Slum. Chicago: University of Chicago Press.

\section{AUTOR}

Vavroch, Michal (1981), sociální antropolog v současnosti studující doktorský program etnologie na Západočeské univerzitě v Plzni. Od roku 2007 se věnuje problematice Romů/Cikánů žijících v sociálně vyloučených lokalitách. V současnosti se zabývá terénním výzkumem zaměřeným na bariéry $\mathrm{v}$ interakci mezi Romy a majoritou.

Kontakt: Mgr. Michal Vavroch, Katedra antropologie Fakulty filozofické Západočeské univerzity v Plzni, Sedláčkova 15, 30614 Plzeň, e-mail: michalvavroch@email.cz 
